\title{
INVESTIGATION OF THE RELATIONSHIP BETWEEN WATCHING PROGRAMS OF SABALAN CHANNEL AND SOCIAL CAPITAL OF ARDEBIL CITIZENS
}

\author{
Ali Amirpoor \\ Department of Social Communication Sciences, Ardabil Science and Research Branch, Islamic Azad \\ University, Ardabil, Iran \\ Ali Jafari \\ Department of Social Communication Sciences, Ardabil Branch, Islamic Azad University, Ardabil, Iran \\ Jafari.communication@gmail.com
}

\begin{abstract}
Objective: This study aimed to investigate the relationship between the social capital citizens Ardebil Sabalan channel to watch the surveying method is done. Methods: This study is a survey using multistage cluster sampling was conducted schema. The population of this research was all Citizens over 20 years of Ardebil, of which 400 were selected through Cochran's formula. Findings: correlation obtained to examine the relationship between the variables showed that applications Sabalan channel direct correlation between social capital and social trust inverse correlation with Solidarity with political participation informal social ties inverse correlation, with correlation faith-based engagement there is an inverse correlation with equity directly and civic participation. However, the correlation between the uses of Sabalan channel programs with Participation and civic leadership, giving \& volunteering, diversity friendship groups. Conclusion: Sabalan channel as one of the factors of socialization in the province of Ardebil, play an important role in the institutionalization of values, norms and social cohesion between the local and national audiences and a total increase of the social capital citizens Ardebil.
\end{abstract}

Keywords: social capital, media, network Sabalan, Citizens Ardebil.

\section{ERDEBİL VATANDAŞLARA ÜZERİNE SABALAN KANAL VE SOSYAL SERMAYENIN IZLEMEK PROGRAMLARI ARASINDAKİ İLIŞKİNIN INCELENMESI}

Öz

Amaç: ölçme yöntemi yapılır izlemek için sosyal sermayenin vatandaşları Erdebil Sabalan kanal arasındaki ilişkinin araştırılması amaçlanmıştır. Yöntem: $\mathrm{Bu}$ çalışma şeması gerçekleştirilmiştir çok aşamalı küme örnekleme yöntemiyle bir araştırmadır. Bu araştırmanın evrenini 400 Cochran formülü ile seçilen hangi Erdebil 20 yıl, her yerinde Vatandaşların oldu. Bulgular: korelasyon değişkenler arasındaki ilişki korelasyon inanç temelli nişan ile siyasal katılım gayrı sosyal bağların ters ilişki, Dayanışma ile sosyal sermaye ve sosyal güven ters korelasyon uygulamaları arasında Sabalan kanalı doğrudan bir korelasyon sermaye ile bir ters ilişki olduğunu gösterdi incelemek elde doğrudan ve sivil katılımı. Ancak, Katılım ve sivil liderlik vererek ve gönüllülük, çeşitlilik dostluk grupları ile Sabalan kanal programlarının kullanımları arasındaki ilişki. Sonuç: Erdebil eyaletinde sosyalleşme faktörlerinden biri olarak Sabalan kanal, değerler, normlar ve yerel ve ulusal kitlelere ve sosyal sermaye vatandaşların Erdebil toplam artış arasındaki sosyal uyum kurumsallaşmasında önemli bir rol oynamaktadır

Anahtar kelimeler: sosyal sermaye, medya, ă̆ Sabalan, Vatandaşlar Erdebil. 


\section{INTRODUCTION}

Today, we face rapid changes in societies especially globalization in its various aspects which make organizations seek for organizational evolutions. On the other hand, society enters to the new era. Quoting from Giyurian (2010) the issue of social capital as a successful entrepreneur leverage a more important role of physical and human capital in society and can be a good platform for the effectiveness of Community organizations (lin \& Erickson, 2010 quoted Giyurian, 2011). Social capital resources that are either out of business or just personal network is available, the sources of information, ideas, tips, business opportunities, financial capital, power, influence, support, emotional, benevolence, trust and collaboration (Baker, 2002). social capital in the system of social norms that promote cooperation of community members and incurs level exchanges and communication costs are (Fukuyama, 2000).create problems such as rising social tension, decrease satisfaction, reduced motivation, turnover and ultimately reduce the organization's efficiency and effectiveness in the community (Rahmani and Kawusi, 2009).

Due to the large and influential mass media in society have a special role in social capital? Different forms of media cause the formation of social capital (increase or decrease), and to shape the imaginations of the environment (Puntam, 1995).

The mass media can access the abstract and specialized institutions provided for your audience and thereby trust or lack of trust to these institutions in their audience (Gidense, 1999).

Another function defined for mass media, social solidarity and social capital trust has an important role in the process. Mc Quail solidarity function of social media is that "finding an insight about different circumstances, social empathy, with others and gain a sense of belonging, find a basis for conversation, social interaction, fill a in real life, social roles and the empowerment of individual help to forge links with family, friends and society (Mc Quail, 2003) will be capital. Taking a look at the breadth and scope of social capital, prospects can strengthen or weaken the impact of the media in the hands of social capital and on the basis of research regarding the impact of mass media on audiences, most effective media belong to media video (TV), audio media and written media (Tonnes, 2009).

The aim of this paper is to investigate the relationship between the amounts of social capital citizens Ardebil Sabalan channel is watching. Some of the hypotheses are:

- Sabalan channel between the watch there is a significant relationship with social capital Citizens Ardabil.

- Between watching programs with trust Citizens Ardebil Sabalan channel there is a significant relationship

- There is significant relationship between the watch with the Political Participation Citizens Ardebil Sabalan channel.

- Between watching programs with Participation and civic leadership Citizens Ardebil Sabalan channel there is a significant relationship.

- Between the watch Informal social ties citizens Ardebil Sabalan channel there is a significant relationship.

- Between the watch Giving \& volunteering citizens Ardebil Sabalan channel with a significant relationship exists. 
- Between watching programs with Faith-based engagement citizens Ardebil Sabalan channel there is a significant relationship.

- Between watching programs with justice in civic participation citizens Ardebil Sabalan channel there is a significant relationship

- Between watching programs with diversity friendship citizens Ardebil Sabalan channel there is a significant relationship.

In this paper, the theory of the "Kennedy" to be used as theoretical framework. The think tank, the following dimensions have been identified.

\section{Trust:}

A: trust social: the main axis of social capital, the question is whether you trust other people have Including trust in people such as neighbor, co-worker, store clerk, a fellow, the police and all those who are in contact with them in everyday life.

B: trust among different ethnic groups: it deals with the extent to which people of other ethnicities is trust social capital, between different races (black, white, and yellow) were investigated and trust in each other 'races to be measured.

\section{Political Participation:}

A: Political Participation Normal: This type of partnership can be of the number of voters, the study and the purchase of newspapers, information Citizens of the political agenda and was measured. B: Political Participation critical: Political Participation Studies show that it may be normal in a society too low, but the community of Political Participation critical, high level, and individuals in activities such as: marches, strikes, boycotts, gatherings, political revolution and have an active presence.

\section{Participation and civic leadership:}

A civic leadership: the degree of participation in civic leadership groups, clubs, associations and the city or school so they pay, and the question of to what extent these individual groups and associations, leadership plays, is considered. People leadership role in groups, clubs, associations and town or school affairs and so are the various forms of civic participation is a form of social capital.

B: civic participation: the extent to which people in a variety of religious groups, sports clubs, youth organizations, parents' associations, groups and charities, cooperatives and trade unions, cultural centers, etc.

\section{Informal social ties:}

Some communities and communities have attempted to develop informal relationships, and membership and participation in non-formal prefer. In fact, the next measurement informal aspects of social capital deal. This dimension, unlike the previous, to assess aspects of informal social capital deals, such as the number of friends a person, the relationship of the individual with his friends in the office environment and outside of it, participate in group games, visit family.

\section{Giving \& volunteering:}

Citizens honorary membership in humanitarian non-governmental organizations and charities and voluntary cooperation of individuals, both financial and intellectual, and spend time, such as social capital.

\section{Faith-based Engagement:}


Religion plays a very important role in social capital. People based on their religion, origin may be involved such as Takaya operating in mosques and churches or places of worship and pilgrimage.

\section{Justice in a civil partnership:}

In some communities people tend to affluent, educated and a very special race and vice versa in some other communities, poor people are the priority. Since these factors are important public health measure draws people in social participation, is important. It could be the next two factors such as race, income, education studied.

\section{Diversity friendship:}

Referring to socialize and fellowship individual is social classes, races and ethnic groups and different religions. In other words, if a person with individuals, classes and groups and belonging to different races and religions in touch with them and find friendships have, as an increase in social capital is (Alvani and Seyed Naghavi, 2001).

\section{METHODS AND INSTRUMENTS}

The research method is according to the purpose and nature of the subject, practical and correlational survey. The Citizens of all adults (20 and older) Ardebil were considered as population. Using Cochran formula, of which 400 were selected by multistage cluster sampling method. Data collection tools include questionnaire was designed. The validity of the questionnaire was used specialists and experts. For reliability Cronbach alpha coefficient was used. 0.70 is calculated alpha for the whole questionnaire. SPSS to analyze the data by using descriptive and inferential statistics is done. The descriptive statistics statistical characteristics are such as frequency, mean, standard deviation, variance and inferential statistics Kolmogorov-Smirnov test and one-sample $t$ and Pearson correlation coefficient was used.

\section{FINDINGS}

According to demographic findings, 50 percent (200) of the male respondents and 50 percent (200) are women. 17\% (69 people) of respondents have high school diploma, 36 percent (143 cases), Diploma and Advanced Diploma, 31 percent (124 people) license and 16\% (64 people) are also on the graduate level. $7 \%$ of respondents in the age range 20 to 30 years, $32 \%$ between the ages of 31 to 40 years, $45 \%$ between the ages of 41 and 50 years old and 16 percent are 51 to 60 years. 17\% (68 patients), the student respondents, 32 percent (128 people) employees, 34 percent (137 cases) free and 17\% (67 people) are also housewives. 60 percent $(n=239)$ of respondents from news programs, 11 percent $(n=42)$ program of entertainment and recreation, 4\% (10) sports programs, 15 percent (60) of movies and series, 3\% (12)of dialogue and $8 \%$ (31 patients) use of other programs. 59 percent of respondents less than 1 hour, $23 \%$ between 1 and 2 hours, $10 \%$ between 2 to 3 hours, 3 percent between 3 and 4 hours and only 5 percent more than five hours of television programs Sabalan channel used them. 71 percent of respondents less than half an hour, 16 percent an hour, two hours 3 percent, 4 percent and 5 percent is three hours longer than four hours of radio programs Sabalan channel they use. Social capital mean and standard deviation of the respondents $(0.45 \pm 3.07)$ shows that there was moderate to high. In other words, the respondents' social capital is in relatively good condition. Among components of social capital, justice, civic participation has the highest average $(0.75 \pm 3.58)$ and social trust has the lowest average $(0.46 \pm 2.4)$.

\section{Use the Citizens Ardebil Sabalan channel program look like?}

In Table 1 the percentage of Sabalan channel programs by Citizens Ardebil is given.

Table (1) - Descriptive statistics of applications Sabalan channel

\begin{tabular}{|c|c|c|c|c|c|c|}
\hline \multicolumn{2}{|c|}{ Replies level } \\
\hline $\begin{array}{c}\text { The use of programs } \\
\text { of Sabalan channel }\end{array}$ & $\begin{array}{c}\text { The amount } \\
\text { of using TV }\end{array}$ & $\begin{array}{c}\text { Less than } \\
1 \text { hour }\end{array}$ & $\begin{array}{c}\text { Between 1 } \\
\text { and 2 hours }\end{array}$ & $\begin{array}{c}2 \text { to } 3 \\
\text { hours }\end{array}$ & $\begin{array}{c}3 \text { to } 4 \\
\text { hours }\end{array}$ & $\begin{array}{c}\text { More than } \\
5 \text { hours }\end{array}$ \\
\hline
\end{tabular}




\begin{tabular}{|c|c|c|c|c|c|c|}
\hline & $\begin{array}{c}\text { The amount } \\
\text { of using } \\
\text { radio }\end{array}$ & $\begin{array}{c}\text { Less than } \\
\text { half an } \\
\text { hour. }\end{array}$ & One hour & $\begin{array}{c}\text { Two } \\
\text { hours }\end{array}$ & $\begin{array}{c}\text { Three } \\
\text { hours }\end{array}$ & $\begin{array}{c}\text { Four hours } \\
\text { and more }\end{array}$ \\
\hline
\end{tabular}

As in Table 1 show, 59 percent of respondents less than 1 hour, 23\% between 1 and 2 hours, 10\% between 2 to 3 hours, 3 percent between 3 and 4 hours and only 5 percent more Sabalan channel 5 hours of TV programs they use. The above data shows the majority of respondents less than one hour of TV programs Sabalan channel they use and this shows that Sabalan channel has performed poorly in the audience.

On the other hand, the above table shows that 71 percent of respondents less than half an hour, 16 percent an hour, two hours 3 percent, 4 percent and 5 percent is three hours longer than four hours of radio programs Sabalan channel use. The above data shows the majority of respondents less than half an hour of radio programs Sabalan channel they use and this shows that Sabalan channel has performed poorly in the audience. In Table (2) Descriptive findings such as mean, standard deviation, minimum and maximum scores of social capital Citizens Ardebil is given.

Table (2) Descriptive statistics of social capital

\begin{tabular}{|c|c|c|c|}
\hline \multicolumn{2}{|c|}{ Variables } & Average & Standard deviation \\
\hline \multirow{4}{*}{$\begin{array}{c}\text { Social capital } \\
\text { components }\end{array}$} & Social capital & $\mathbf{3 . 0 7}$ & $\mathbf{0 . 4 5}$ \\
\cline { 2 - 4 } & Social trust & 2.4 & 0.46 \\
\cline { 2 - 4 } & Participation and civic leadership & 2.68 & 0.71 \\
\cline { 2 - 4 } & Informal social ties & 3.22 & 0.71 \\
\cline { 2 - 4 } & Giving \& volunteering & 3.48 & 0.73 \\
\cline { 2 - 4 } & Faith-based Engagement & 3.21 & 0.64 \\
\cline { 2 - 4 } & Justice in civic participation & 3.58 & 0.93 \\
\cline { 2 - 4 } & Diversity friendship & 2.95 & 0.75 \\
\hline
\end{tabular}

Respondents' social capital mean and standard deviation $(0.45 \pm 3.07)$ shows that there was moderate to high. Among components of social capital, justice, civic participation has the highest average $(0.75 \pm$ $3.58)$ and social trust has the lowest average $(0.46 \pm 2.4)$.

Table (3) Results of the correlation between the use of Sabalan channel programs and social capital

\begin{tabular}{|c|c|c|c|}
\hline Independent variable & Dependent variable & $\begin{array}{l}\text { The amount of } \\
\text { relationship }\end{array}$ & Significant level (P) \\
\hline \multirow{8}{*}{  } & Social capital & $0.143 *$ & 0.05 \\
\hline & Social trust & $-0.194 * *$ & 0.03 \\
\hline & Political Participation & $0.174 * *$ & 0.04 \\
\hline & $\begin{array}{l}\text { Participation and civic } \\
\text { leadership }\end{array}$ & -0.077 & 0.125 \\
\hline & Informal social ties & $-0.115^{*}$ & 0.05 \\
\hline & Giving \& volunteering & 0.02 & 0.688 \\
\hline & Faith-based Engagement & $0.195^{*}$ & 0.03 \\
\hline & $\begin{array}{c}\text { Justice in civic } \\
\text { participation }\end{array}$ & $-0.129 * *$ & 0.000 \\
\hline
\end{tabular}




\begin{tabular}{|l|l|l|l|}
\hline & Diversity friendship & 0.059 & 0.243 \\
\hline
\end{tabular}

*. Correlation is significant at the 0.05 level (2-tailed).

**. Correlation is significant at the 0.01 level (2-tailed).

The results of the Pearson correlation coefficient $(\mathrm{r}=0.143)$ and significance level $(\alpha=0.05)$ shows that statistically at the level of error of less than $\mathrm{P}<0.05$ a weak positive correlation between the use of programs Sabalan channel and social capital. In other words, what the applications Sabalan channel will increase as the social capital citizens increases. The correlation obtained to investigate the relationship between research showed that social capital between the applications Sabalan channel and direct and significant correlation $(\mathrm{r}=0.143$ and $\alpha=0.05)$, inverse correlation with social trust $(\mathrm{r}=-0.194$ and $\alpha=0.03)$, with a direct correlation Political Participation $(r=0.174 \& \alpha=0.04)$, the Informal social ties inverse correlation ( $\mathrm{r}=-0.115$ and $\alpha=0.05$ ), with Faith-based Engagement direct correlation $(\mathrm{r}=0.195$ and $\alpha=0.03$ ) and civic participation is negatively correlated with equity $(\mathrm{r}=-0.129$ and $\alpha=0.000)$ there. But the correlation between the use of Sabalan channel programs with Participation and civic leadership, Giving $\&$ volunteering, Diversity friendship groups.

\section{RESULTS}

Results showed that between watching programs with social capital citizens Ardebil Sabalan channel there is a significant positive correlation. Citizens of the program so that more Sabalan channel that have high social capital. The results of this study with previous results Hosseinpour and Motamednezhad (2011), Giyurian (2012) who have reported a positive correlation between media and social capital is consistent.

As a result of this study can be explained using the idea of planting media Graebner. Graebner as the most important theorist planting focusing his studies on Citizens who are at high levels of television viewing and comparing it with the people who watch TV less argues that "the hungry crowd, the TV actually sources of information, awareness of monopolizing his thoughts and make a bowl. The effects of exposure to produce something similar messages that Graebner as "planting" reads or common worldview training, roles and values of the Age "(Severin and Tankard, 2002). It can be concluded from discussions concluded planting the idea that television is a medium through which many of our conception of the world around me and therefore could lead to increased social capital.

The results can be significant inverse correlation between the use of mass media and social trust Citizens Ardebil noted. This finding is consistent with research results Javaheri and Balakhani (2006) and Heydari (1998) and Dehghani (2011) is consistent. This result is also in line with the views Kolman (1998) and Pantham (2003) the relationship between the use of the mass media, including social capital and social trust. The results showed that between watching programs with Political Participation Citizens Ardebil Sabalan channel there is a significant positive correlation. Citizens of the programs so that they are more Sabalan channel Political Participation them, are these findings with results Amir Entekhabi and Heyrannia (2011) and Moy (2002) is consistent. Radio and television as the most effective mass media play an important role in shaping public opinion during elections, since participation is achieved when people come to the conclusion that the decision-making process corporately

Other results of this research are that between the use of the Citizens Ardebil Sabalan channel programs and social ties there is an inverse relationship. This means that the Citizens spend a lot of time to watch television programs, as well as the relevance and Informal social ties (relationships with family, neighbors, friends and relatives and informal groups) are reduced. This finding is in line with the theory Pantham (1998) is obtained. It Pantham (1980) Citizens leisure to spend with family, neighbors or community and civic participation were already going to watch TV. In this regard he writes many facts indicate that the variety of communication technologies are actively looking for private leisure time and 
thus prevent the formation of social capital, he knows the most important tools TV. Research in the 1960s showed that the growth in time spent watching television and other forms of life have influenced people day and night (Puntam, 1995).

The results showed that between watching programs with Faith-based Engagement Citizens Ardebil Sabalan channel there is a significant positive correlation. TV Graebner means to be a community of people, in a word, TV function, cultural function, a TV output systematic messages through its message, the whole community is affected as a result of the impact of socialization» (Greener, 1969) to create social capital and its components.

The local media Ardebil Sabalan channel as an effective role in shaping people's attitudes towards the environment and the people in it. The media shape the imaginations of the environment, they can provide your own image or blowing from the community of trust among your audience increase or decrease. The media contribute to the formation of patterns of action in between the audience and the patterns of action to help people in different situations to take action.

Finally, Sabalan channel as one of the factors of socialization in the province of Ardebil, play an important role in the institutionalization of values, norms and social cohesion between the local and national audiences, and in general enhance the social capital citizens Ardebil.

\section{RESEARCH SUGGESTIONS}

- Recommended Sabalan channel with the review and rethink the form and content of their plans to improve and expand the content of their social capital.

- Sabalan channel to the demands and needs of different segments of society on the other hand, the activities of government officials disclose information to thereby produce social capital to engage

- Recommended that the mass media especially network television in the province of Ardebil Sabalan more effort to attract audiences to take action and create a positive attitude in the minds of your audience, pay more attention to them.

- Recommended Sabalan channel Ardebil by showing complete and accurate picture of social reality Ardebil, publication of timely, accurate and comprehensive news and no censorship of news and information, domain trust society in the spread.

- Recommended in Sabalan channel plans to pay special attention to customs and local culture. - Interactions between different sectors of society more and more managers Ardebil Sabalan channel with the formation of the media committee, holding periodic meetings to report on actions taken and discussion with media professionals in the field of solutions development social capital essential.

- Now in developing countries, including Iran, people are not dominant media literacy good enough and responsible task is that people applying procedures to promote media literacy. Elevating the purpose of media literacy is to vaccinate people against the psychological effects of media products.

\section{REFERENCE}

Alvani, S.M and Seyed Naghavi, M.A. 2001. Social Capital: Concepts and Theories, Journal of Management Studies, No. 33 and 34, pp. 26-3

Bourdieu, p. 1986. "the forms on capital" in: jack. Richardson(Ed), Handbook of theory and research for the sociology of education, New York: green wood press.

Gerbner, G. 1967. "Mass Media and Human Communication Theory", in Dance. F.E.X. (ed.), Human Communication Theory, New York: Holt, Rinehart and Winston. 
Gidense, A. 1999. Modernity and dignity in modern society. Translate Nasser Movafaghian. Tehran: Reed Publishing.

Giyurian, H. 2012. The effect of media on social capital, The Journal of Media Studies, Vol. VII, Issue 16 , Pages 37-29

Hosseinpour, J and Motamednezhad, K. 2011. Examine the relationship between media consumption and social capital of citizens, welfare and social development planning magazine, Issue 6, Pages 174-129

Javaheri, F and Balakhani, GH. 2006. Social media and trust: the impact of mass media on social trust (Case Study citizens), Journal of Social Sciences Faculty of Literature and Humanities University of Mashhad, Issue 1, pp. 29-1

Kolman SJ. 1998. Foundations of social theory, translation M. patience, Tehran: Reed Publishing

Mc Quail, D. 2003. Introduction of social communication, translation Parviz Ejlali, Tehran: Media Research Center

Moy, P. 2000. Media effects on political and social trust, Journalism and mass communication quarterly, 77(4), p, 744-770

Puntam, Robert, D. 1995. Tuning in, Tunin out : the strange disappearance of social capital in America, the American prospect, Inc

Severin, V and Tankard, J 2002. the theory of mass communication, translation Dehghan, Tehran, Tehran University publishing, printing.

Tonnes, AS. 2009. Mass communication theory and research, translation Naim novel, Tehran: News 